International Journal of Engineering \& Technology, $7(2.28)(2018) 20-23$
International Journal of Engineering \& Technology
SPC
Website: www.sciencepubco.com/index.php/IJET
Research paper

\title{
A Hybrid Modeling of Long-Term Electricity Consumption Forecasting Based on ARIMA and ANN: The Case of Thailand with Projection
}

\author{
Nattapon Jaisumroum ${ }^{1 *}$, Jirarat Teeravaraprug ${ }^{2}$ \\ ${ }^{1,2}$ Department of Industrial Engineering, Faculty of Engineering, Thammasat University, Thailand \\ *Corresponding author E-mail: nattaponj89@gmail.com
}

\begin{abstract}
Modeling and forecasting of electricity consumption can provide reliable guidance for power operation and planning in developing countries such as Thailand. In this study, formulates the effects of two different historical data type is modeled by auto regressive integrated moving averaged (ARIMA) and artificial neural network (ANN) based on population and gross domestic product per capita (GDP). The derived model is validated by various statistical approaches such as the determination coefficient. Additionally, the performances of the derived model are assessed using mean absolute percentage error (MAPE), root mean square error (RMSE) and mean absolute error (MAE). Three scenarios are used for forecasting Thailand's electricity consumption in $2011-2015$. The simulation results are validated by actual data sets observed from 1993 to 2010. Empirical results showed that the proposed method has higher accuracy compared to single ARIMA and artificial intelligence based models.
\end{abstract}

Keywords: ARIMA; Hybrid Forecasting Model; Neural Network; Thailand Electricity Consumption

\section{Introduction}

Electrical energy is vital important foe development of every country from the economic and environmental perspective with the last decades presenting a sequence of crisis in the sector, the government, state, enterprise and electrical.

Electrical companies are looking for accurate models with the ability to reflect the best predictions of electricity consumption in an unstable economy scenario.

The investment on infrastructure and operation trends to produce better results when they are based on linearity scenarios.

To cope with the uncertainties on demand and mitigate the risks of economic and financial loses; the decision making is based on long term demand forecasts [1].

As electrical is a crucial input to industrial part of the country, electrical demand increase along with the industrial function increase. Rapid changes in industry and economy strongly affect electricity consumption. Therefore, electricity consumption is an important economical index that represents economic development of a city or the country [2]. As over the past decade global energy consumption has increased rapidly because of population and economic growth [3], [4].

According to wide growth of electricity consumption in the last decade, electrical demand management is very important for achieving economic success, environment preservative and suitable planning for existing resources that result in self-sufficiency and economic development. Therefore, various techniques have been used for electrical demand management to forecast future electrical demands accurately [4].
According to the time horizon, the electricity consumption forecasting is classified as short-term, medium-term and long-term forecasting.

Short-term forecasting (Several days ahead in hourly steps) has attracted substantial due to its importance for power system control, economic dispatch and order of unit commitment in electricity markets.

Medium-term forecasting (Several months ahead in weekly steps) is especially interesting for companies operating in a deregulated environment, as it provides them with valuable information about the market need of electricity, scheduling the maintenance of the units and electrical imports/exports.

Long-term forecasting (Years ahead in annual steps) has been always playing a vital role in power system management and planning. The long-term forecast directly impacts on effectiveness of electrical trading, system reliability, operation and maintenance costs and generator scheduling. Moreover, accurate long-term forecasting can provide reliable guidance for power consumption planning, which is important for the sustainable development of all countries.

For long-term planning, all approaches for forecasting require historical data as statistical models for electricity consumption forecasting while dependent and independent variables face too much fluctuation, Table 1 outlines the summary of all approaches. One of the most important and widely used time series models is the auto regressive integrated moving average (ARIMA) model, Box-Jenkins methodology and Grey model (GM) in the modelling process [5].

Although ARIMA models are quite flexible as they can represent several different types of times series, their major limitation is the pre-assumed linear form of the model. 
Artificial neural network (ANN) is the most important and widely used techniques among the artificial intelligence based approaches, applied in the field of energy management [6] - [9]. Despite the performance of ANN methods for electricity consumption forecasting based on the input historical data [10], [11]. Summary of studies on long-term electricity consumption forecasting for various countries showed in Table 1 .

Table 1: Summary of Studies on Long-Term Electricity Consumption Forecasting for Various Methods Countries.

\begin{tabular}{|c|c|c|c|c|}
\hline Methods & Country & Period & Input Variables & $\begin{array}{c}\text { MAPE } \\
(\%)\end{array}$ \\
\hline \multicolumn{5}{|c|}{ Single Methods } \\
\hline ANFIS & G7 [13] & $\begin{array}{l}2008- \\
2015\end{array}$ & GDP, POP & 1.49 \\
\hline SVM & $\begin{array}{l}\text { Taiwan } \\
{[14]}\end{array}$ & $\begin{array}{l}1981- \\
2000\end{array}$ & $\begin{array}{l}\text { Previously ob- } \\
\text { served values }\end{array}$ & 1.29 \\
\hline KBES & Egypt [15] & $\begin{array}{l}1981- \\
2007\end{array}$ & $\begin{array}{l}\text { Years, Tempera- } \\
\text { ture }\end{array}$ & 1.33 \\
\hline GP & $\begin{array}{l}\text { Turkey } \\
{[16]}\end{array}$ & $\begin{array}{l}2004- \\
2010\end{array}$ & $\begin{array}{l}\text { Previous de- } \\
\text { mand, Climate }\end{array}$ & 1.16 \\
\hline Data mining & $\begin{array}{l}\text { Turkey } \\
{[14]}\end{array}$ & $\begin{array}{l}1980- \\
2025\end{array}$ & $\begin{array}{l}\text { Previously ob- } \\
\text { served values }\end{array}$ & 3.25 \\
\hline GEP & $\begin{array}{l}\text { Thailand } \\
\text { [17] }\end{array}$ & $\begin{array}{l}1986- \\
2009\end{array}$ & $\begin{array}{l}\text { GDP, POP, EXP, } \\
\text { Stock index }\end{array}$ & 0.37 \\
\hline PSO & Iran [18] & $\begin{array}{l}1982- \\
2030\end{array}$ & $\begin{array}{l}\text { GDP, POP, IMP, } \\
\text { EXP }\end{array}$ & 1.16 \\
\hline ACS & Iran [19] & $\begin{array}{l}1992- \\
2030\end{array}$ & $\begin{array}{l}\text { GDP, POP, IMP, } \\
\text { EXP,Stock index }\end{array}$ & 0.75 \\
\hline $\mathrm{ABC}$ & $\begin{array}{l}\text { Turkey } \\
{[20]}\end{array}$ & $\begin{array}{l}1979- \\
2025\end{array}$ & $\begin{array}{l}\text { GDP, POP, IMP, } \\
\text { EXP }\end{array}$ & 2.26 \\
\hline \multicolumn{5}{|c|}{ Combined Methods } \\
\hline PSO-GA & Iran [21] & $\begin{array}{l}1980- \\
2006\end{array}$ & $\begin{array}{l}\text { GDP, POP, } \\
\text { Number of cus- } \\
\text { tomers }\end{array}$ & 0.98 \\
\hline $\begin{array}{l}\text { Fuzzy-data } \\
\text { mining }\end{array}$ & Iran [19] & $\begin{array}{l}1995- \\
2005\end{array}$ & $\begin{array}{l}\text { Previous ob- } \\
\text { served values }\end{array}$ & 2.00 \\
\hline ANN-PSO & $\begin{array}{l}\text { Iran, USA } \\
{[16]}\end{array}$ & $\begin{array}{l}1967- \\
2030\end{array}$ & $\begin{array}{l}\text { GDP, POP, IMP, } \\
\text { EXP }\end{array}$ & 1.51 \\
\hline ANN-GA & Iran [22] & $\begin{array}{l}1981- \\
2008\end{array}$ & $\begin{array}{l}\text { Price number of } \\
\text { customers, value } \\
\text { added }\end{array}$ & 3.68 \\
\hline $\begin{array}{l}\text { Simulated- } \\
\text { ANN }\end{array}$ & Iran [18] & $\begin{array}{l}1994- \\
2005\end{array}$ & $\begin{array}{l}\text { Previously ob- } \\
\text { served values }\end{array}$ & 1.80 \\
\hline GRNN-FOA & China [23] & $\begin{array}{l}1978- \\
2012\end{array}$ & $\begin{array}{l}\text { Previously ob- } \\
\text { served values }\end{array}$ & 1.15 \\
\hline $\begin{array}{l}\text { Simulation- } \\
\text { ANFIS }\end{array}$ & Iran [24] & $\begin{array}{l}1994- \\
2005\end{array}$ & $\begin{array}{l}\text { Previously ob- } \\
\text { served values }\end{array}$ & 1.55 \\
\hline SVR-DE & China [15] & $\begin{array}{l}1987- \\
2008\end{array}$ & $\begin{array}{l}\text { Previously ob- } \\
\text { served values }\end{array}$ & 1.10 \\
\hline $\begin{array}{l}\text { LS-SVM- } \\
\text { FOA }\end{array}$ & China [25] & $\begin{array}{l}1998- \\
2011\end{array}$ & $\begin{array}{l}\text { Previously ob- } \\
\text { served values }\end{array}$ & 1.03 \\
\hline $\begin{array}{l}\text { Optimized } \\
\text { GM }\end{array}$ & $\begin{array}{l}\text { Turkey } \\
{[26]}\end{array}$ & $\begin{array}{l}1945- \\
2025\end{array}$ & $\begin{array}{l}\text { Previously ob- } \\
\text { served values }\end{array}$ & 3.28 \\
\hline ARIMA-PSO & China [27] & $\begin{array}{l}2006- \\
2010\end{array}$ & $\begin{array}{l}\text { Previously ob- } \\
\text { served values }\end{array}$ & 2.19 \\
\hline Fuzzy-GA & China [28] & $\begin{array}{l}1990- \\
2010\end{array}$ & $\begin{array}{l}\text { Previously ob- } \\
\text { served values }\end{array}$ & 7.45 \\
\hline GP-SA & $\begin{array}{l}\text { Thailand } \\
\text { [29] }\end{array}$ & $\begin{array}{l}1986- \\
2009\end{array}$ & $\begin{array}{l}\text { GDP, POP, EXP, } \\
\text { Stock index }\end{array}$ & 0.50 \\
\hline MLP-ANN & $\begin{array}{l}\text { Greece } \\
{[30]}\end{array}$ & $\begin{array}{l}2010- \\
2015\end{array}$ & $\begin{array}{l}\text { Previously ob- } \\
\text { served values }\end{array}$ & 2.19 \\
\hline ANN-Fuzzy & India [31] & $\begin{array}{l}2006- \\
2010\end{array}$ & $\begin{array}{l}\text { Previously ob- } \\
\text { served values }\end{array}$ & 1.76 \\
\hline GD-ANN & Iran [32] & $\begin{array}{l}2010- \\
2030\end{array}$ & $\begin{array}{l}\text { GDP, POP, IMP, } \\
\text { EXP }\end{array}$ & 5.41 \\
\hline PSO-ANN & Iran [32] & $\begin{array}{l}2010- \\
2030\end{array}$ & $\begin{array}{l}\text { GDP, POP, IMP, } \\
\text { EXP }\end{array}$ & 5.02 \\
\hline IPSO-ANN & Iran [32] & $\begin{array}{l}2010- \\
2030\end{array}$ & $\begin{array}{l}\text { GDP, POP, IMP, } \\
\text { EXP }\end{array}$ & 1.94 \\
\hline
\end{tabular}

\section{Arima-Hybrid Forecasting Model}

Both ARIMA and ANN models have good performance in linear and non-linear structures but none of them is comprehensive to be able to forecast various time series structures. The studies showed that using dissimilar models improve time series forecasting where data set or pattern is varying and unstable [12]. The ARIMA and soft computing techniques improves precision of energy demand forecasting [4].

In other proposed methodology, time series $\left(y_{t}\right)$ is considered as a function of linear and nonlinear component. Zhang [5] proposed a hybrid model that consists of two steps: step (1) is applying linear model and step (2) is applying nonlinear model using linear model's residuals. The proposed forecasting system is shown in Figure 1.

$$
y_{t}=f\left(L_{t}, N_{t}\right)
$$

Where, $L_{t}$ denoted the linear part and $N_{t}$ denotes the nonlinear part, one of the most efficient models in improving forecast accuracy, can establish the additive relationship between linear and nonlinear parts. Consequently can write

$$
y_{t}=L_{t}+N_{t}
$$

\section{Problem description and methodology}

In this section, ARIMA-ANN hybrid patterns are employed according to the methods. In the first step, after forecasting electricity consumption with ARIMA, its errors which are differences between actual and forecasted consumptions are calculated and forecasted using population and GDP.

The design hybrid forecasting of ARIMA and ANN models for electricity consumption is show in Figure 2. Therefore, the proposed ensemble based ARIMA-ANN hybrid models were used in forecasting. The independent variables, including the following: population and gross domestic product per capita (GPP) used as inputs to the models in electricity consumption forecasting. It seems that these two factors have the most impact on electricity consumption, population and GPP data from 1993 to 2015, were used for modelling electricity consumption. The data were collected from statistics of Thailand are show in Table 2. The data set trends similarity of historical data show in Figure 3. The data were divided into train and test sets, where data for 1993-2010 is used for training of the models and that for 2011-2015 is utilized for testing of the models show in Figure 4.

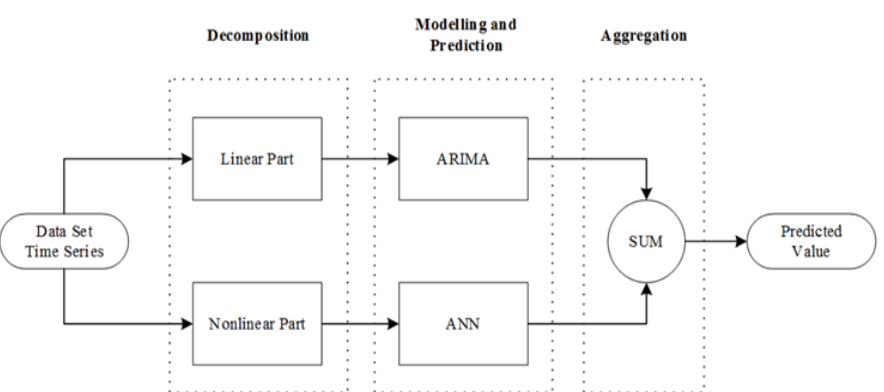

Fig. 1: A hybrid forecasting system 
Table 2: Electricity Consumption, Population and GPP Data from 1993 to 2015

\begin{tabular}{|c|r|r|r|}
\hline Year & $\begin{array}{c}\text { Electricity Consumption } \\
\text { (Million Kilowatt hour) }\end{array}$ & $\begin{array}{c}\text { Population } \\
\text { (Million) }\end{array}$ & $\begin{array}{c}\text { GDP per Capita } \\
\text { (Million Baht) }\end{array}$ \\
\hline 1993 & $64,822.35$ & 58.44 & $74,281.18$ \\
\hline 1994 & $74,165.28$ & 59.24 & $79,138.03$ \\
\hline 1995 & $82,152.89$ & 59.28 & $85,506.51$ \\
\hline 1996 & $84,886.99$ & 59.90 & $89,404.59$ \\
\hline 1997 & $82,672.77$ & 60.50 & $86,080.51$ \\
\hline 1998 & $83,566.15$ & 61.20 & $78,599.93$ \\
\hline 1999 & $89,861.03$ & 61.80 & $81,395.76$ \\
\hline 2000 & $93,296.41$ & 61.88 & $84,912.57$ \\
\hline 2001 & $100,684.30$ & 62.31 & $87,231.01$ \\
\hline 2002 & $107,171.40$ & 62.80 & $91,872.26$ \\
\hline 2003 & $114,541.11$ & 63.08 & $98,040.14$ \\
\hline 2004 & $117,853.49$ & 61.97 & $106,072.70$ \\
\hline 2005 & $124,483.46$ & 62.42 & $109,718.12$ \\
\hline 2006 & $130,364.02$ & 62.83 & $114,417.28$ \\
\hline 2007 & $132,882.14$ & 63.04 & $120,234.11$ \\
\hline 2008 & $133,829.35$ & 63.39 & $121,633.63$ \\
\hline 2009 & $147,720.59$ & 63.53 & $120,469.56$ \\
\hline 2010 & $147,227.81$ & 63.88 & $128,803.27$ \\
\hline 2011 & $158,153.16$ & 64.08 & $129,471.74$ \\
\hline 2012 & $159,265.90$ & 64.46 & $138,015.33$ \\
\hline 2013 & $127,375.84$ & 64.79 & $141,022.70$ \\
\hline 2014 & $163,552.79$ & 65.12 & $141,455.27$ \\
\hline 2015 & $164,345.35$ & 65.72 & $144,116.01$ \\
\hline & & & \\
\hline & & & \\
\hline
\end{tabular}

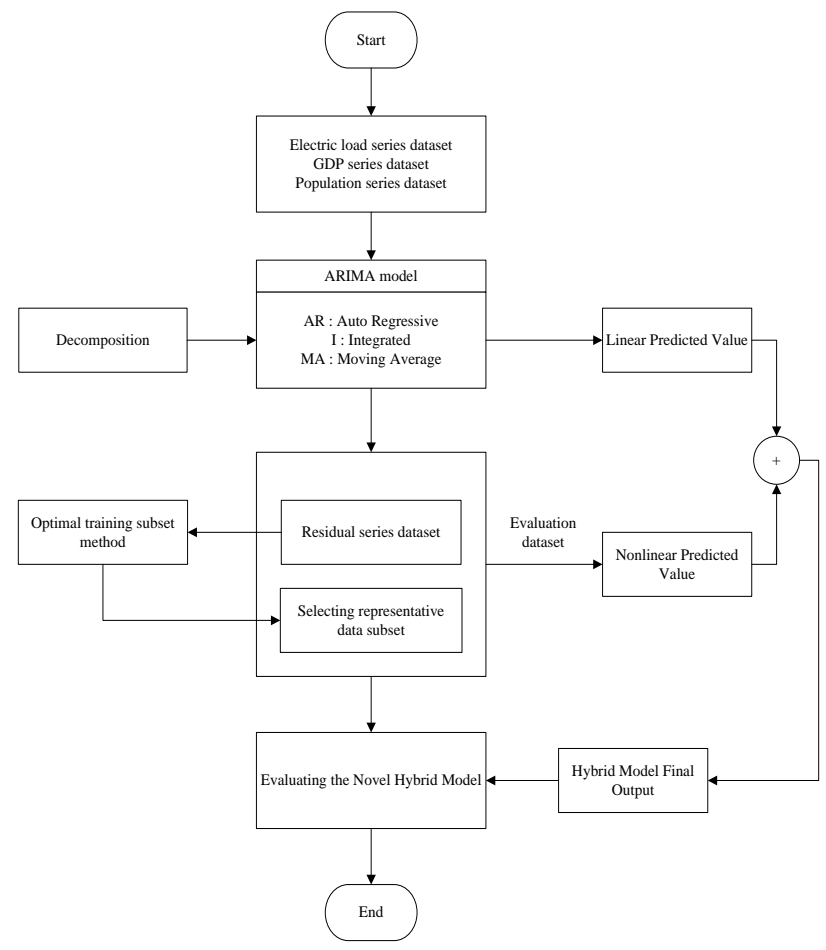

Fig. 2: The Design Hybrid Forecasting of ARIMA and ANN Models for Electricity Consumption

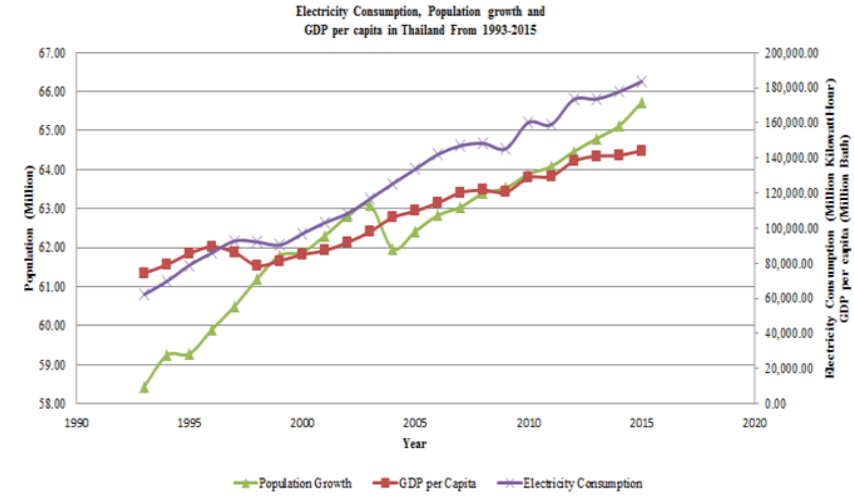

Fig. 3: Data Set Trends Similarity of Historical Data

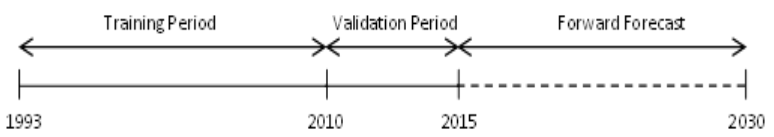

Fig. 4: Process timeline

\section{Results and discussion}

To evaluate the prediction performance of the proposed hybrid model we carry out prediction experiment using a single model ARIMA, ANN. Using the Root Mean Square Error (RMSE), the Mean Absolute Error (MAE) and the Mean Average Percentage Error (MAPE) are formally given in (3) - (5)

$\operatorname{RMSE}=\sqrt{\frac{1}{N} \sum_{t=1}^{N}\left(y_{t}-\hat{y}_{t}\right)^{2}}$

$\mathrm{MAE}=\frac{1}{N} \sum_{t=1}^{N}\left|y_{t}-\hat{y}_{t}\right|$

MAPE $=\frac{1}{N} \sum_{t=1}^{N}\left|\frac{y_{t}-\hat{y}_{t}}{y_{t}}\right|$

Where $N$ is the size of the test set, and $\hat{y}_{t}$ is the predicted value of $y_{t}$.

The forecast evaluation results are reported in Table 3. It shows that the ARIMA-ANN model outperforms all techniques in term of prediction accuracy. The proposed ARIMA-ANN model prediction error is the smallest for all evaluation criteria show in Figure 5. The superior performance of all the ARIMA, ANN and ARIMA-ANN models can be seen in Figure 6, cumulative error tend to remain close to zero, while the ARIMA model's cumulative error deviate from zero more dramatically. The additional beneficial impact of including exogenous variables in the model can also be seen by the ARIMA-ANN model's cumulative error remaining close to zero.

Table 3: The Prediction Errors for The ARIMA, ANN and ARIMA-ANN

\begin{tabular}{|l|c|c|c|}
\hline \multicolumn{1}{|c|}{ Models } & RMSE & MAE & MAPE (\%) \\
\hline ARIMA & 0.7699 & 0.5580 & 13.95 \\
\hline ANN & 0.0645 & 0.0258 & 10.90 \\
\hline ARIMA-ANN & $\mathbf{0 . 0 3 5 8}$ & $\mathbf{0 . 0 1 3 2}$ & $\mathbf{6 . 4 7}$ \\
\hline
\end{tabular}

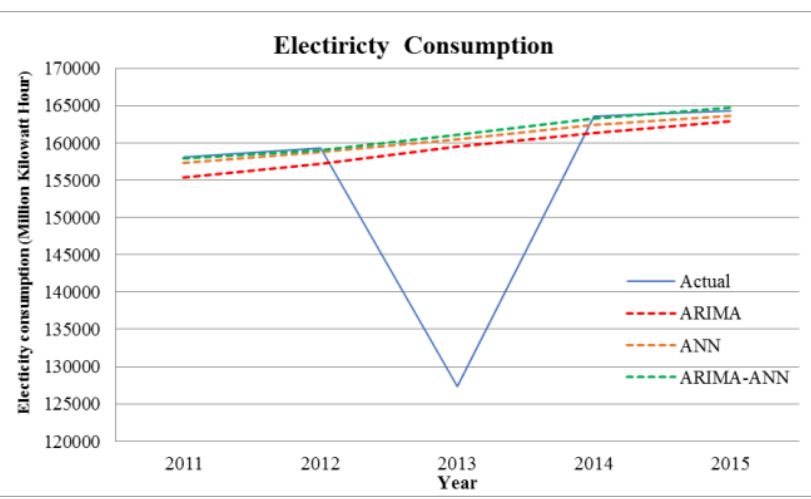

Fig. 5: Forecast Evaluation Results Comparison 


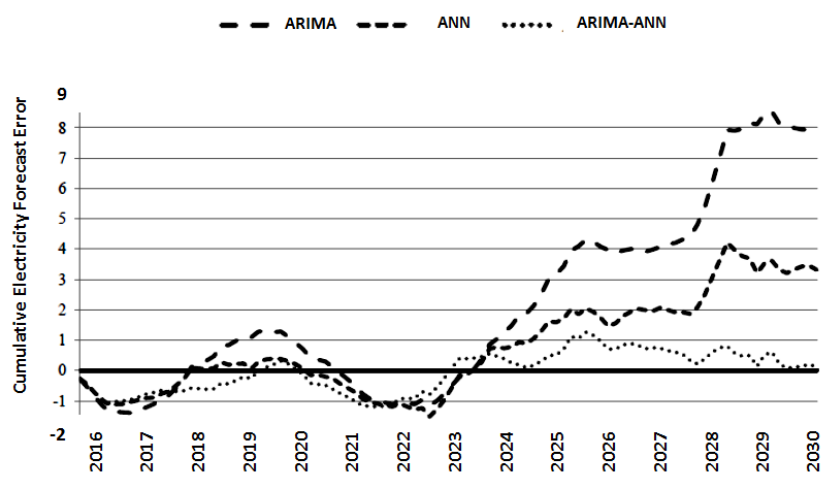

Fig. 6: Cumulative Error Results

\section{Conclusion}

In this study, a hybrid ARIMA-ANN models for long-term electricity consumption forecasting using two different historical data types are developed. The solution framework is implemented for Thailand, as developing and developed economies. Based on the lowest MAPE, the results demonstrate that ARIMA-ANN is the most accurate models, it achieves the MAPE. Moreover, in this study, the effects of implementing dataset on accuracy of Thailand forecasting are examined. Therefore, the proposed model leads to improved performance. It can be an effective way in the forecasting task, especially when higher forecasting accuracy is needed. This procedure supports the validity of the suggested forecasting method.

\section{Acknowledgement}

This study was supported scholarship by Faculty of Engineering, Thammasat University and we also thank anonymous reviewers and colleagues who have given valuable comments to improve quality of this paper.

\section{References}

[1] Wang, Xifan, and James Rufus McDonald. Modern power system planning. McGraw-Hill Companies, 1994.

[2] Lee, Yi-Shian, and Lee-Ing Tong. "Forecasting energy consumption using a grey model improved by incorporating genetic programming." Energy Conversion and Management 52.1 (2011): 147 152.

[3] Ekonomou, L. "Greek long-term energy consumption prediction using artificial neural networks." Energy 35.2 (2010): 512-517.

[4] Suganthi, L., and Anand A. Samuel. "Energy models for demand forecasting - A review." Renewable and sustainable energy reviews 16.2 (2012): 1223-1240

[5] Zhang, G. Peter. "Time series forecasting using a hybrid ARIMA and neural network model." Neurocomputing 50 (2003): 159-175.

[6] Sözen, Adnan, Erol Arcaklioğlu, and Mehmet Özkaymak. "Turkey's net energy consumption." Applied Energy 81.2 (2005): 209221.

[7] Ekonomou, L. "Greek long-term energy consumption prediction using artificial neural networks." Energy 35.2 (2010): 512-517.

[8] Kankal, Murat, et al. "Modeling and forecasting of Turkey's energy consumption using socio-economic and demographic variables." Applied Energy 88.5 (2011): 1927-1939.

[9] Kialashaki, Arash, and John R. Reisel. "Development and validation of artificial neural network models of the energy demand in the industrial sector of the United States." Energy 76 (2014): 749-760

[10] Roy, Sumit, et al. "Development and validation of a GEP model to predict the performance and exhaust emission parameters of a CRDI assisted single cylinder diesel engine coupled with EGR." Applied Energy 140 (2015): 52-64.

[11] Zhang, G. Peter. "Time series forecasting using a hybrid ARIMA and neural network model." Neurocomputing 50 (2003): 159-175.
[12] Suganthi, L., S. Iniyan, and Anand A. Samuel. "Applications of fuzzy logic in renewable energy systems-a review." Renewable and Sustainable Energy Reviews 48 (2015): 585-607.

[13] Nadimi, Vahid, et al. "An Adaptive-Network-Based Fuzzy Inference System for Long-Term Electric Consumption Forecasting (2008-2015): A Case Study of the Group of Seven (G7) Industrialized Nations: USA, Canada, Germany, United Kingdom, Japan, France and Italy." Computer Modeling and Simulation (EMS), 2010 Fourth UKSim European Symposium on. IEEE, 2010.

[14] Hong, Wei-Chiang. "Electric load forecasting by support vector model." Applied Mathematical Modelling 33.5 (2009): 2444-2454.

[15] Wang, Jianjun, et al. "An annual load forecasting model based on support vector regression with differential evolution algorithm." Applied Energy 94 (2012): 65-70.

[16] Ardakani, F. J., and M. M. Ardehali. "Long-term electrical energy consumption forecasting for developing and developed economies based on different optimized models and historical data types." Energy 65 (2014): 452-461.

[17] Nadimi, Vahid, et al. "An Adaptive-Network-Based Fuzzy Inference System for Long-Term Electric Consumption Forecasting (2008-2015): A Case Study of the Group of Seven (G7) Industrialized Nations: USA, Canada, Germany, United Kingdom, Japan, France and Italy." Computer Modeling and Simulation (EMS), 2010 Fourth UKSim European Symposium on. IEEE, 2010.

[18] Azadeh, A., S. F. Ghaderi, and S. Sohrabkhani. "A simulated-based neural network algorithm for forecasting electrical energy consumption in Iran." Energy Policy 36.7 (2008): 2637-2644.

[19] Azadeh, Ali, et al. "A hybrid simulation-adaptive network based fuzzy inference system for improvement of electricity consumption estimation." Expert Systems with Applications 36.8 (2009): 1110811117.

[20] Azadeh, Ali, et al. "A hybrid simulation-adaptive network based fuzzy inference system for improvement of electricity consumption estimation." Expert Systems with Applications 36.8 (2009): 1110811117.

[21] Amjadi, M. H., H. Nezamabadi-Pour, and M. M. Farsangi. "Estimation of electricity demand of Iran using two heuristic algorithms." Energy Conversion and Management 51.3 (2010): 493-497.

[22] Azadeh, Ali, et al. "Improved estimation of electricity demand function by integration of fuzzy system and data mining approach." Energy Conversion and Management 49.8 (2008): 2165-2177.

[23] Li, Hong-Ze, et al. "A hybrid annual power load forecasting model based on generalized regression neural network with fruit fly optimization algorithm." Knowledge-Based Systems 37 (2013): 378387.

[24] Azadeh, Ali, et al. "A hybrid simulation-adaptive network based fuzzy inference system for improvement of electricity consumption estimation." Expert Systems with Applications 36.8 (2009): 1110811117.

[25] $\mathrm{Li}$, Hongze, et al. "Annual electric load forecasting by a least squares support vector machine with a fruit fly optimization algorithm." Energies 5.11 (2012): 4430-4445.

[26] Hamzacebi, Coskun, and Huseyin Avni Es. "Forecasting the annual electricity consumption of Turkey using an optimized grey model." Energy 70 (2014): 165-171

[27] Wang, Yuanyuan, et al. "Application of residual modification approach in seasonal ARIMA for electricity demand forecasting: A case study of China." Energy Policy 48 (2012): 284-294.

[28] Liu, Xiaojuan, and Jian'an Fang. "Long-term load forecasting based on a time-variant ratio multiobjective optimization fuzzy time series model." Mathematical Problems in Engineering 2013 (2013).

[29] Mostafavi, Elham Sadat, et al. "A novel machine learning approach for estimation of electricity demand: An empirical evidence from Thailand." Energy conversion and management 74 (2013): 548-555.

[30] Ekonomou, L. "Greek long-term energy consumption prediction using artificial neural networks." Energy 35.2 (2010): 512-517.

[31] Padmakumari, K., K. P. Mohandas, and S. Thiruvengadam. "Long term distribution demand forecasting using neuro fuzzy computations." International Journal of Electrical Power \& Energy Systems 21.5 (1999): 315-322.

[32] Ardakani, F. J., and M. M. Ardehali. "Long-term electrical energy consumption forecasting for developing and developed economies based on different optimized models and historical data types." Energy 65 (2014): 452-461. 